Vol.1 No.2, Summer 2020

\title{
The effect of religious attitudes (religiosity) on resilience of cancer patients
}

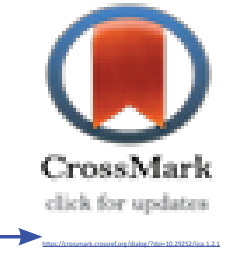

\author{
Jangi Aghdam $\mathrm{Kh}^{1 *}$, Sardari $\mathrm{B}^{2}$
}

1- Positive Psychology Student, Department of Educational Sciences and Psychology, Islamic Azad University, Khoy, Khoy, Iran.

2- Assistant Professor, Department of Educational Sciences and Psychology, Islamic Azad University, Khoy Branch, Khoy, Iran.

Corresponding Author: Jangi Aghdam Kh, Positive Psychology Student, Department of Educational Sciences and Psychology, Islamic Azad University, Khoy, Khoy, Iran.

Email: psychologyclinical1994@gmail.com

Received: 21 March 2019

Accepted: 11 May 2019

\section{Abstract}

Introduction: Studies have shown that spirituality is one of the main strategies in cancer patients. The purpose of this study was to determine the effect of religious attitudes (religiosity) on the resilience of cancer patients in Khoy.

Method: This research is an applied research in terms of purpose and is descriptive-correlative in terms of method. The statistical population of the study, according to the information obtained from hospitals in Khoy city, was identified as 149 cancer patients. According to Morgan's table, the sample size was 108 people who were selected through accessible sampling. To collect information, a religious attitude questionnaire Serajzadeh (2009) and Conner and Davidson (2003) Sustainability Questionnaire. For data analysis, Pearson correlation and regression analysis were used by SPSS software version 21.

Results: Data analysis showed that religious attitudes (religiosity) have a positive and significant effect on the resilience of cancer patients, so that religious attitudes and its components (belief dimension, religious emotional dimension, consequence dimension and ritual dimension) Has a positive and significant resonance in cancer patients $(\mathrm{P}<0 / 01)$.

Conclusion: Based on these findings, it can be concluded that religious attitudes are an effective and effective factor in the resilience of cancer patients.

Keywords: Religious Attitudes, Resiliency, Cancer Patients.

\begin{tabular}{|l|l|}
\hline \multicolumn{3}{|c|}{ Access this article online } \\
\hline & Website: \\
\hline www.ijca.ir
\end{tabular}




\title{
بر بـى تاثير نكر شهاى مذهبى بر تاب آورى بيماران سرطانى
}

\author{
خديجه جنكَى اقدم'،: باقر سردارى \\ ا - دانشجوى روانشناسى مثبت نكر، كروه علوم تربيتى و روانشناسى، دانشخاه آزاد اسلامى، واحد خوى، خوى خوى، ايران.

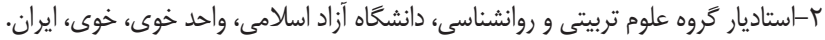

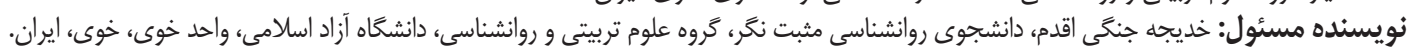
ايميل: psychologyclinical1994@gmail.com

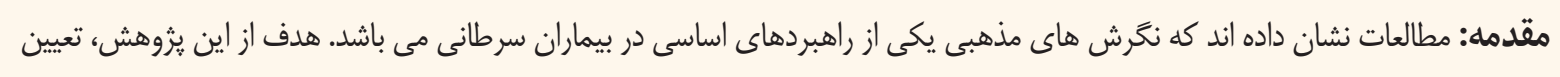

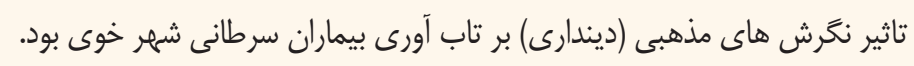

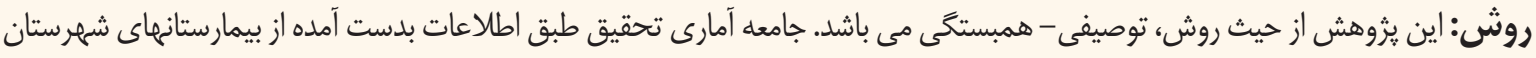

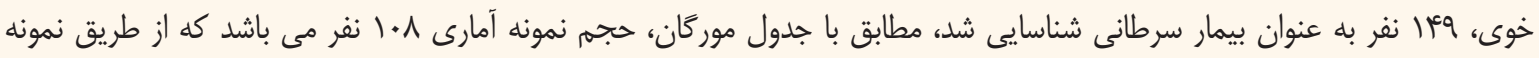

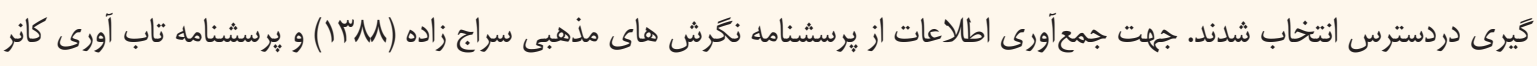

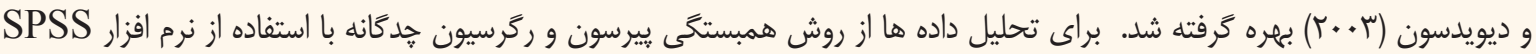
نسخه اب |ستفاده شد.

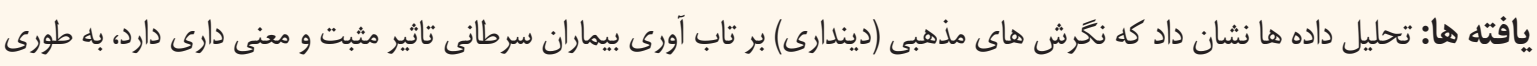

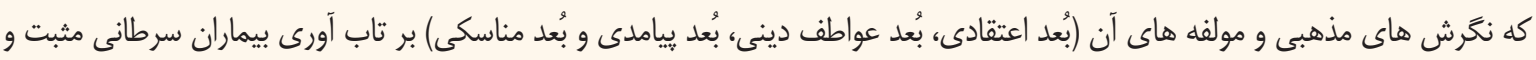

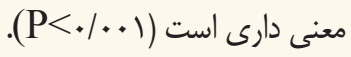
نتيجه كَيرى: مبتنى بر ایى يافته ها مى توان نتيجه كَرفت كه نحَرش هاى مذهبى يكى عامل كارآمد و موثر در تاب آورى بيماران سرطانى كليد وازه ها: نخرش هاى مذهبى، تاب آورى، سرطان.

شوك يِيجيده اي خواهند شد و تحمل اين شرايط براى آنها بسيار

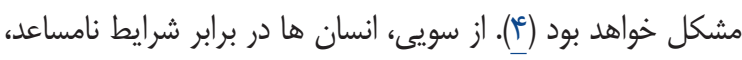

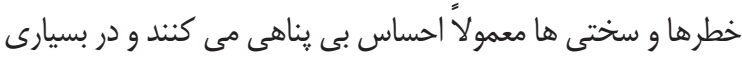

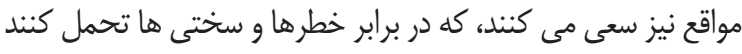

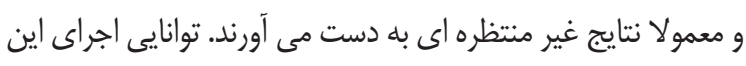

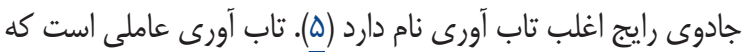

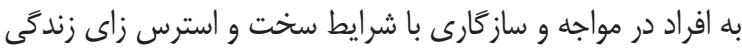

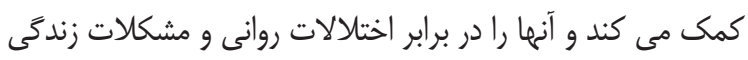

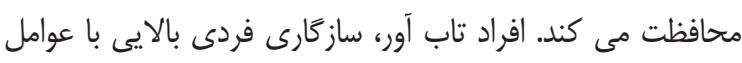

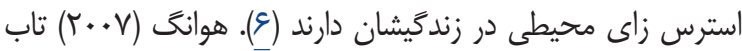
آورى را به عنوان روشى براى اندازه كيرى توانايى فرد در مقابله با داب

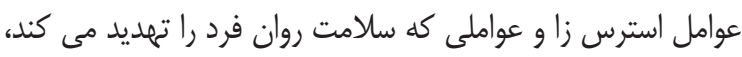

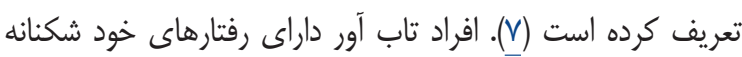

\section{مقلدمه}

سرطانها كروهى از بيمارى ها با تنوع حدود يك صد نوع مختلف بوده، كه ناشى از رشد بدخيم سلولهياى بدن هستند، سلول كو خكترين

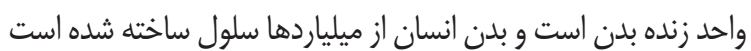

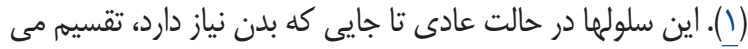

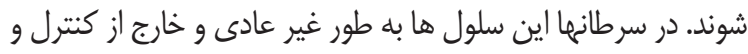

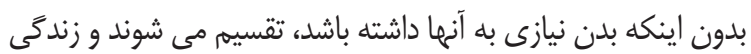
عادى سلولها را در معرض خطر و تهاجم قرار مى دهند (َ). بـراى بيمـاران مبتلا به سرطان كه در مراحل انتهايى بيمـارى خود فراد

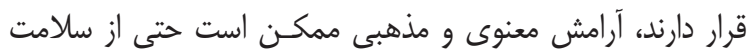

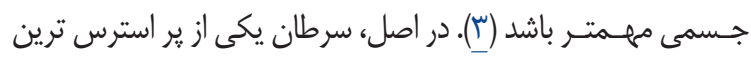
رخ داد هايى است كه افراد در زندگى خود با آن برخورد مى كنتد (1). معمولا بيماران در رو به رو شدن با تشخيص سرطان، دهار ضربه و ورداب 
برخوردارى از حمايت هاى اجتماعى و حمايت روحانى همخى از جمله

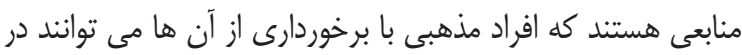

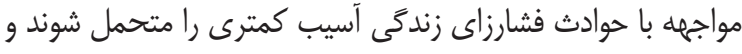

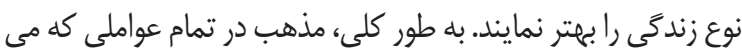

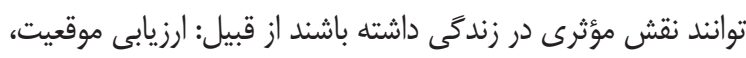

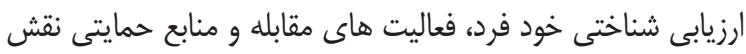
موثرى دارد (ع). تحقيقات در خصوص تاثيرات ديندارى مويد اين

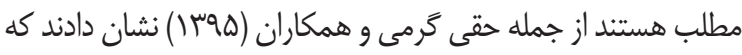

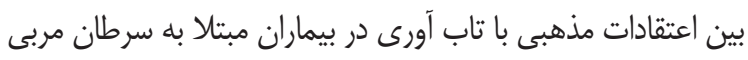
همبستگى معنادارى وجود داشت (IV). همجنين، حريفى (هوسا)

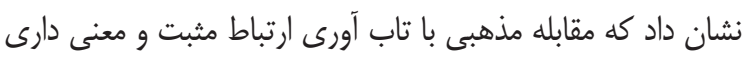

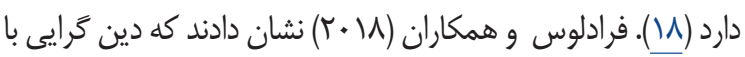

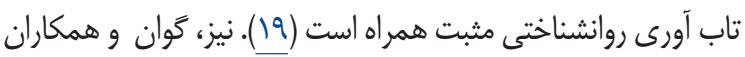

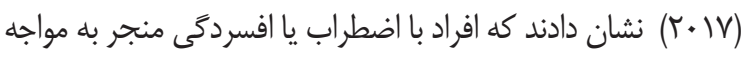
بيشتر مذهبى منفى مى شوند و دين دارى غير سازمانى كمترى

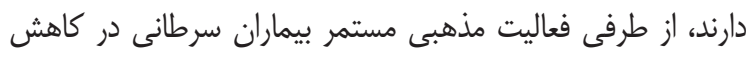

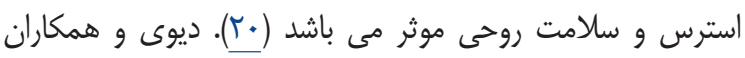

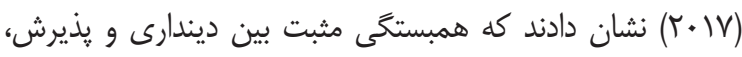

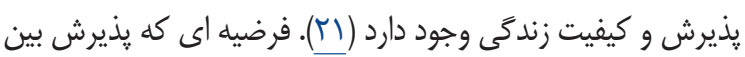

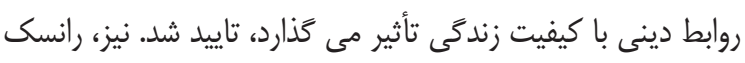

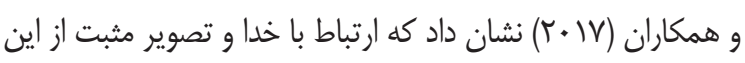

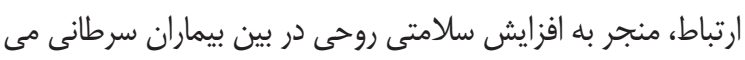

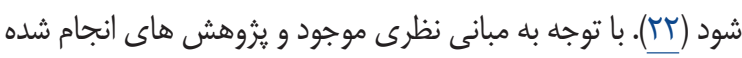

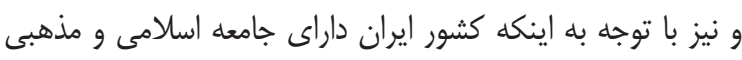
بوده و باورهاى مذهبى نقش مهمى در زندكى تمامى افراد جامعل

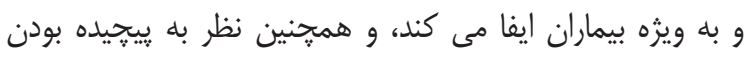

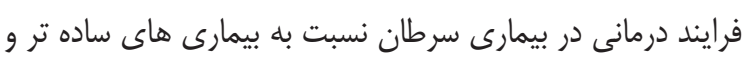

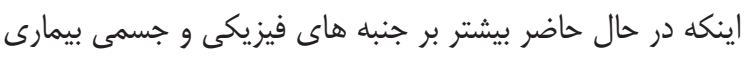

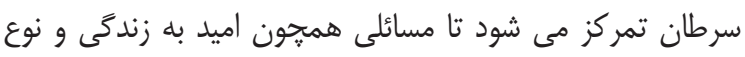

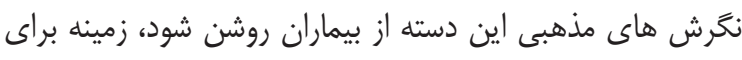

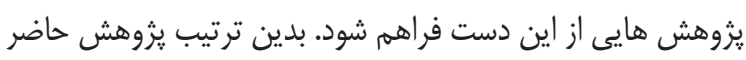

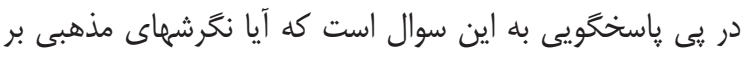

تاب آورى بيماران سرطانى تاثير دارد؟

\section{روش مطالعه}

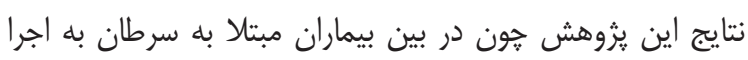

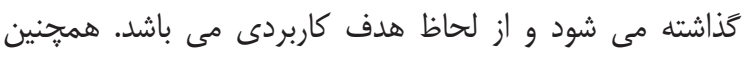

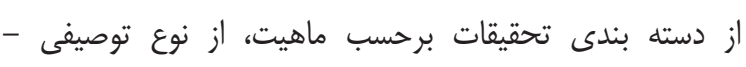

نيستند. از نظر عاطفى آرام بوده و توانايى مقابله با شرايط ناكوار

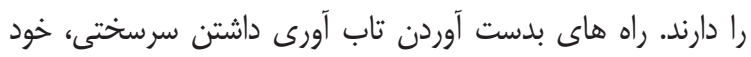

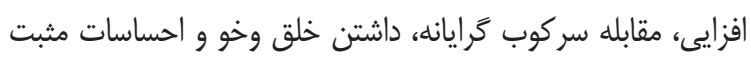

مى تواند باشد (1).

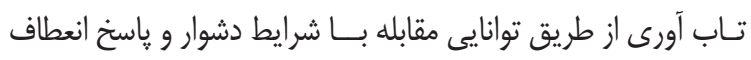

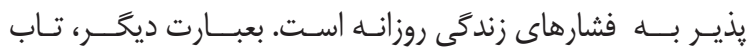

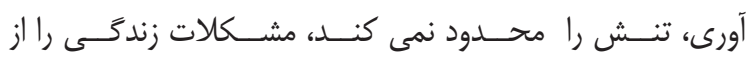

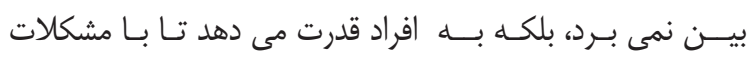

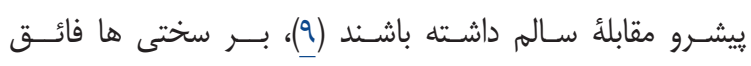

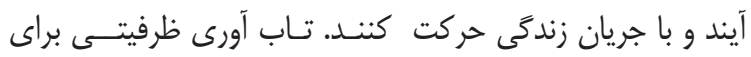

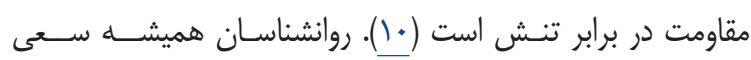

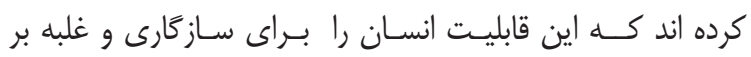

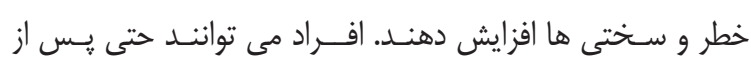

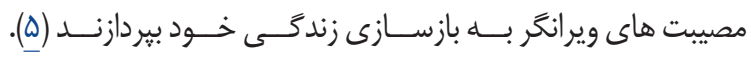

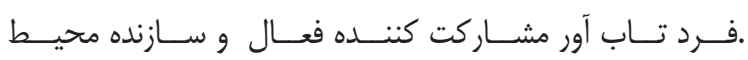

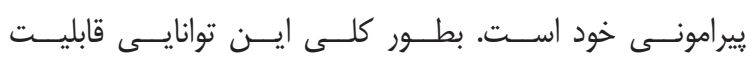

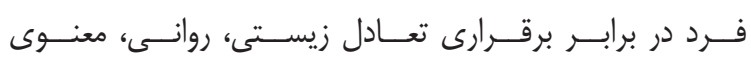

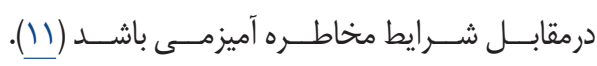
از طرفى، به دليل طبيعت تهديد كننده سرطان، تشخيص اين بيمارى

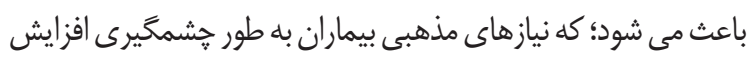

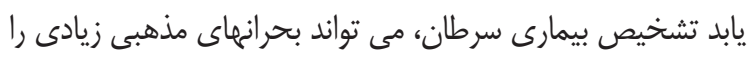

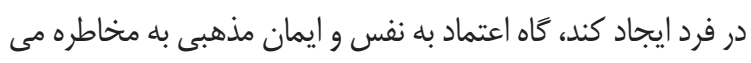

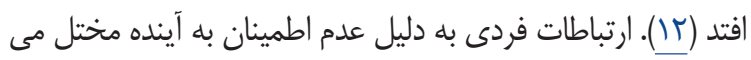

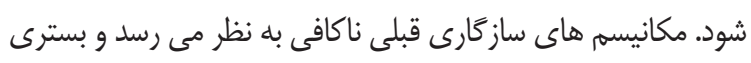

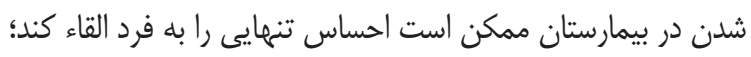

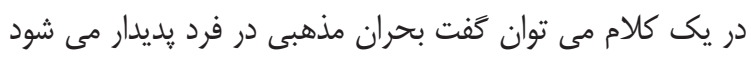

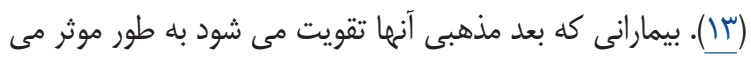

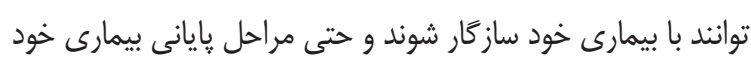

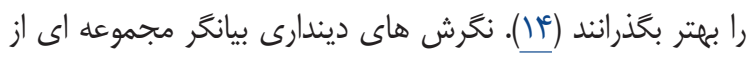

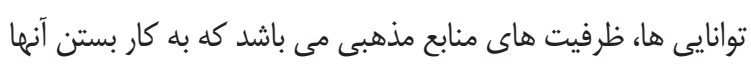

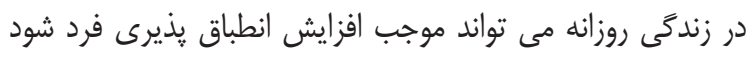

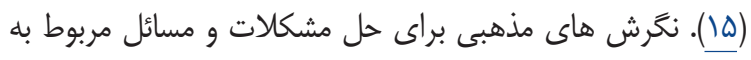

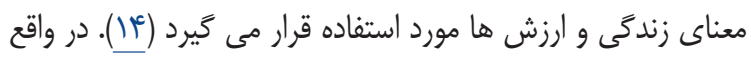

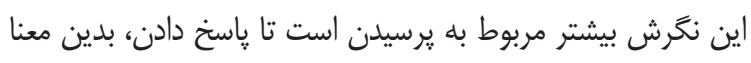

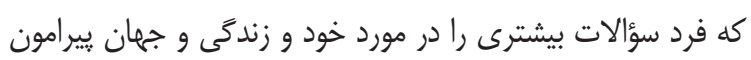

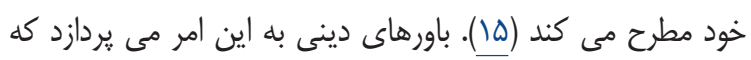
داشتن معنا و هدف در زندگىى، احساس تعلق داشتن به منبعى والا،

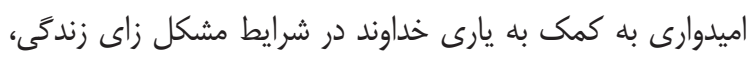


صورت مثبت نمره كذارى مى شود. اين مقياس در ايران توسط

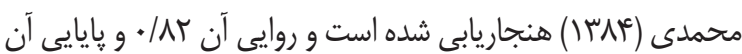

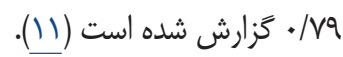

\section{يافته ها}

همانطور كه قيد شد نمونه آمارى شامل 1 +ا نفر از بيماران سرطانى شهرستان خوى مى باشد كه توصيف فراوانى ويثگى هاى نمونه آمارى در جداول ذيل به نمايش در آمده است:

جدول ا: توصيف جنسيت بيماران مبتلا به سرطان شهرستان خوى

\begin{tabular}{|c|c|c|}
\hline درصد & تعداد & جنس \\
\hline 91 & $v^{\pi}$ & مرد \\
\hline r & ro & زن \\
\hline $1 \ldots$ & 1.1 & جمع \\
\hline
\end{tabular}

در (جدول ())، درصد مردو زن درج كرديده است.

جدول T: توصيف طول مدت بيمارى، بيماران مبتلا به سرطان شهرستان خوى

\begin{tabular}{|c|c|c|}
\hline درصد & تعداد & طول مدت بيمارى \\
\hline rq & re & ا الى" سال \\
\hline re & rv & ع الى \& سال \\
\hline rv & ז & V الى. ا و بالاتر \\
\hline $1 .$. & $1 \cdot 1$ & جمع \\
\hline
\end{tabular}

در (جدول r)، طول مدت بيمارى شركت كنندكان در يزوهش درج

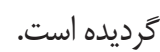

همبستىى مى باشد.جامعه آمارى تحقيق طبق اطلاعات بدست

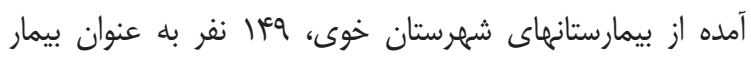

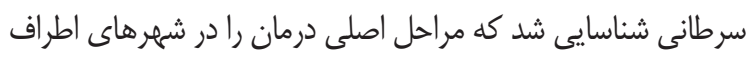
شهرستان خوى، طى مى كنند. مطابق با جدول مور كان، حجم نمونه أمارى 1+ ا نفر مى باشد كه از طريق نمونه كَيرى در دسترس انتخاب

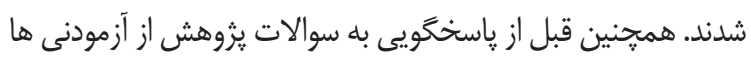
رضايت نامه اخلاقى كسب كرديد و يزوهشكَر متعهد كرديد كه نتايج

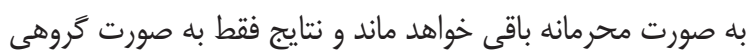
تحليل خواهند شد. در اين يزوهش از دو يرسشنامه استفاده شد. به منظور اندازه كيرى

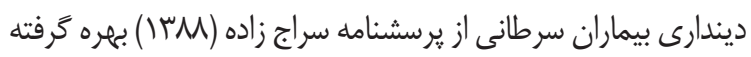

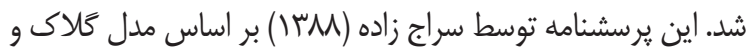

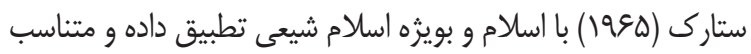

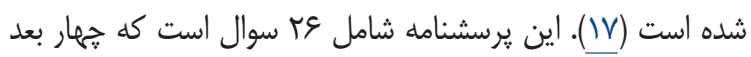

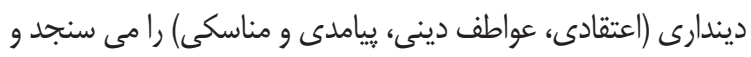
نحوه نمره كذارى به صورت طيف ليكرت از التا ه خواهد بود. يايايى

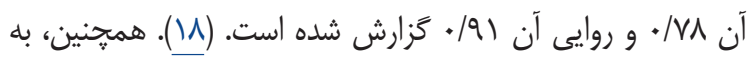

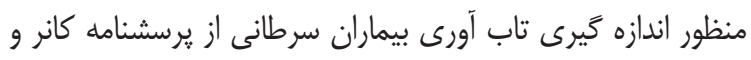

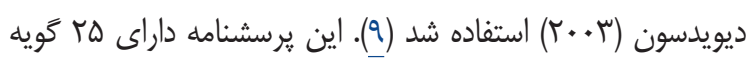

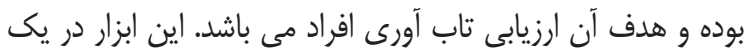

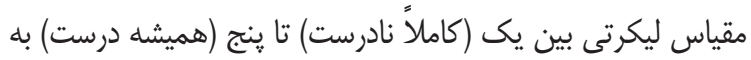
جدول سا: آماره هاى توصيف متغير نخرش هاى مذهبى و تاب آورى

\begin{tabular}{|c|c|c|c|c|}
\hline حداكثر & حداقل & انحراف معيار & ميانتَين & متغير \\
\hline 114 & שו & Tr/T. & $V T / M I$ & نخرش هاى مذهبى (ديندارى) \\
\hline 栏 & 9 & V/re & $r \cdot l \cdot v$ & بُعد اعتقادى \\
\hline tr & $\wedge$ & 91.9 & $\mid \mathrm{V} / \Delta \Lambda$ & بُعد عواطف دينى \\
\hline ru & $\checkmark$ & G/T & $\mid \varepsilon / \mu^{\prime}$ & بُعد ييامدى \\
\hline 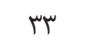 & 9 & $\varepsilon / \Delta \Delta$ & $N \cdot G$ & بُعد مناسكى \\
\hline ar & (i) & $9 / \Delta 1$ & $\Delta F / V$ & تاب آورى \\
\hline
\end{tabular}

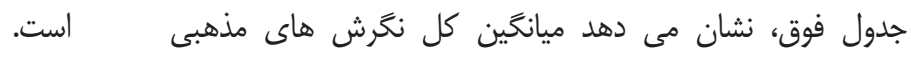
با عنايت به (جدول ع)، سطح معنى دارى متغير ديندارى و مولفه هاى (ديندارى) (

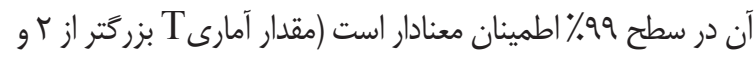
عمل آمده، نتيجه آزمون كولموكروف-اسميرنوف، به دليل بالا بودن

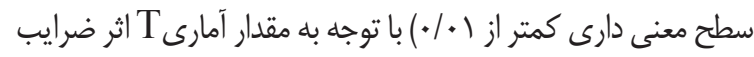

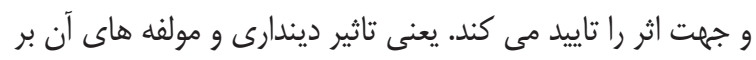
سطح معنى دارى بالاتر از ه.٪. دادههاى مربوط متغيرهاى تحقيق

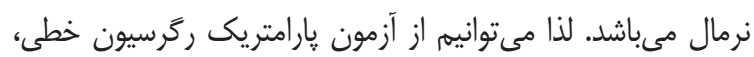
ميزان تاب آورى مثبت و مستقيم است و با افزايش ميزان ديندارى و

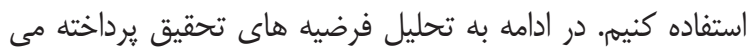
مولفه هاى آن متغير تاب آورى به تبع آن افزايش مى يابد.

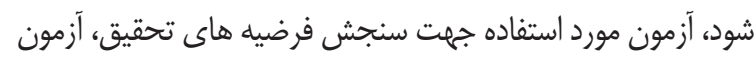
ركرسيون خطى است، كه نتايج آن در (جدول ع) به نمايش درآمده 


\section{خديجه جنَّى اقدم و باقر سردارى}

جدول f: ركَر سيون بررسى تاثير نكَرش هاى مذهبى (ديندارى) و مولفه هاى آن بر تاب آورى بيماران سرطانى

\begin{tabular}{|c|c|c|c|c|c|c|c|}
\hline سطح معنى دارى & $\mathbf{F}$ & درجه آزادى & $\mathrm{T}$ & Beta & خطاى معيار & B & متغيرها \\
\hline & & 1 & $10 / 8$ & & $r / T \cdot q$ & $r F / \Delta \Lambda$ & \multirow{2}{*}{ ديندارى } \\
\hline.$/ .1$ & 91/89 & 1.9 & $Q / \Delta \vee G$ & $\cdot|9 \Lambda|$ &.$/ . r q$ & . /TVq & \\
\hline & & 1 & $\Delta / V \gamma \Delta$ & & $r / N \in q$ & $T / / \& Q T$ & \multirow{2}{*}{ بُعدد اعتقادى } \\
\hline.$/ . .1$ & T & 1.9 & F/ATr & . KTD & ./IVG & $\cdot / \Lambda \Delta$. & \\
\hline & & 1 & $\Delta / / T /$ & & r/Ar) & $19 / 919$ & \multirow{2}{*}{ بُعد عواطف دينى } \\
\hline.$/ . .1$ & rv/vqq & 1.9 & $D / T V T$ &.$/ F \Delta s$ & $\cdot \pi \cdot 9$ & $1 / \cdot 19$ & \\
\hline & & 1 & $V / T \& A$ & & $\Gamma / \Lambda$ & TV/SIS & \multirow{2}{*}{ بُعدد بيامدى } \\
\hline.$/ . .1$ & q/q9V & 1.9 & &.$/ 4 q$ & . TIV & $.19 \mathrm{WV}$ & \\
\hline & & 1 & $r / A r)$ & & Wאוא/T & $19 / 099$ & \multirow{2}{*}{ بُعد مناسكى } \\
\hline.$/ . .1$ & $199 / 999$ & 1.9 & s/AT) & - $/ \Delta Q T$ & ./IVq & 1/TMY & \\
\hline
\end{tabular}

در تبيين اين يافته ها مى توان كفت، افزايش تاب آورى و در نتيجه

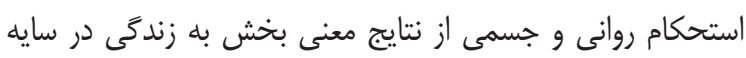
ديندارى است. تقويت باورهاى دينى و معنوى مى تواند با تغيير در

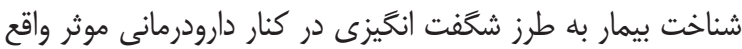

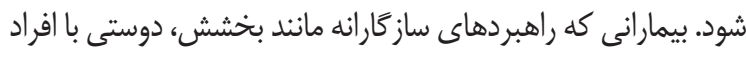

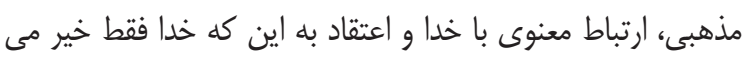

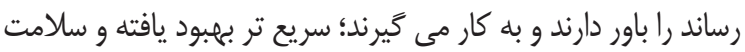

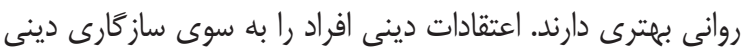

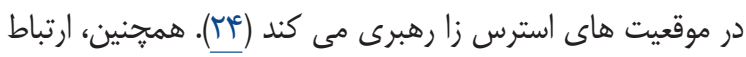

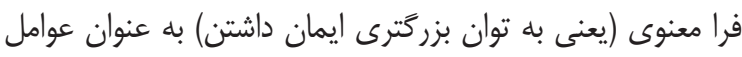
حمايتى فردى به سوى ايجاد و تسهيل تابآورى ياد شده است و

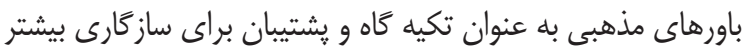

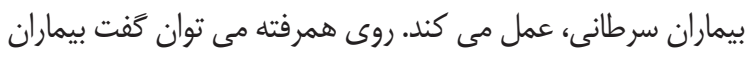

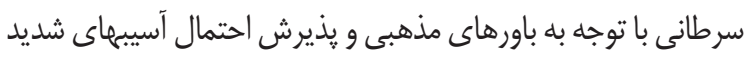
جسمى و روانى به كمك ايمان و نكَرش دينى، به ساز كارى و تاب

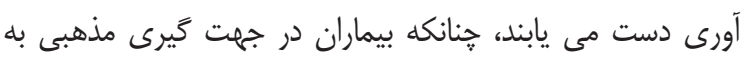

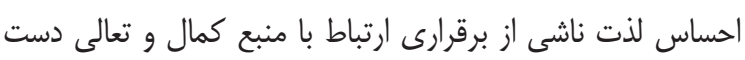

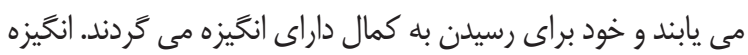

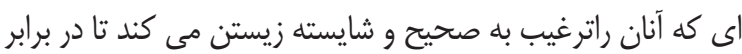

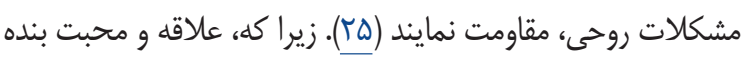

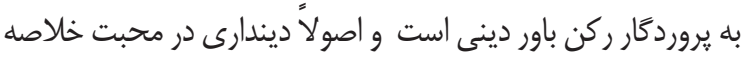

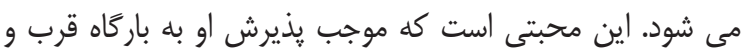

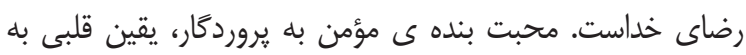

طبق يافته هاى بدست آمده از تحليل رَّرسيون خطى، نخرش هاى

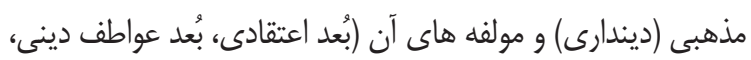

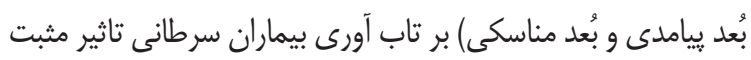

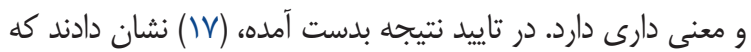

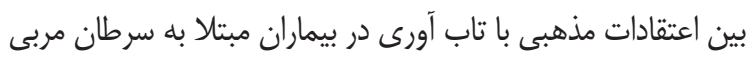
همبستخى مثبت و معنادارى وجود دارد. در واقع، زمانى كه بيماران سرطانى به يك خاستخاه والا باور دارد و

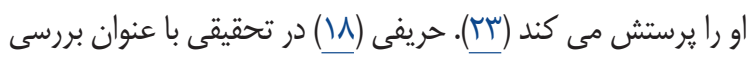

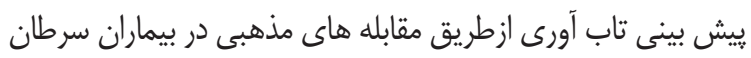

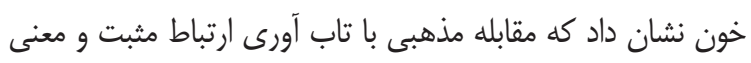

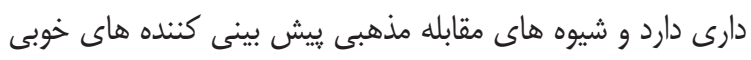

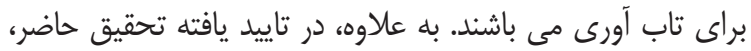

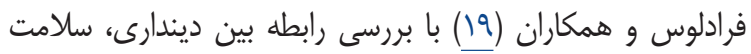

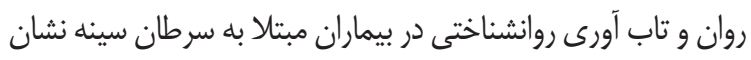

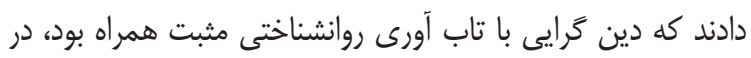
حالى كه هيج ارتباطى با افسردىى، اضطراب و بار نشانه الى يافت

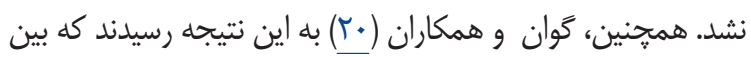

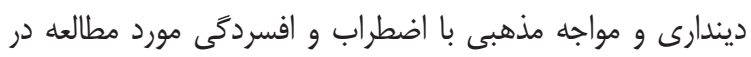
بيماران سرطانى، افراد با اضطراب يا افسردگى منجر به مواجه بيشتر مذهبى منفى مى شوند و دين دارى غير سازمانى كمترى دارند. از

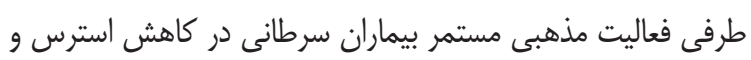

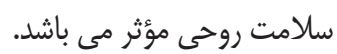


در آن مشغول درمان مى باشند) از روحانيون سرشناس يا كارشناسان

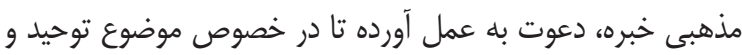
اعتقاد، براى بيماران جامعه تحقيق، مطالب مربوطه را اريه دهند. همجنين، انجمن حمايت از بيماران سرطانى، نسبت به اجراى مراسم دعا ادقام نموده و مطالب اعتقاد به توحيد را در خنين مراسم هايى صورت جذاب به ايشان ارايه شود. به علاوه، انجمن حمايت از بيماران سرطانى تا حد امكان، نسبت به شركت دادن بيماران در اردوهاى زيارتى (راهيان نور، شهرهاى مذهبى خارج از كشور و ...) اقدم نمايند. يزوهش حاضر داراى محدوديت هايى بود از جمله اينكه روش نمونه گيرى به صورت در دسترس بوده است و همجنين ميزان كم حجم نمونه نيز از ديخر محدوديت هاى يزوهش حاضر مى باشد. ييشنهاد مى گردد در مطالعات آينده از روش نمونه گيرى تصادفى استقاده شود و همجنين تعداد نمونه بيشترى انتخاب شود تا تعميم نتايج بهتر

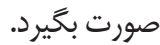

\section{نتيجه تيرى}

مبتنى بر يافته هاى يزوهش حاضر مى توان نتيجه گرفت كه ايمان و نخَرش مذهبى، بردبارى بيماران سرطانى را در برابر سختيما افزايش

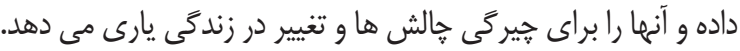

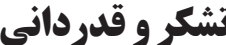

يزروهش حاضر ماحصل يايان نامه كارشناسى ارشد رشته روانشناسى

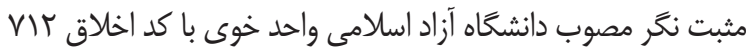
مى باشد. نويسند محترم تشكر و قدردانى بعمل آورند

\section{References}

1. Deka SJ, Mamdi N, Manna D, Trivedi V. Alkyl Cinnamates Induce Protein Kinase C Translocation and Anticancer Activity against Breast Cancer Cells through Induction of the Mitochondrial Pathway of Apoptosis. J Breast Cancer 2016; 19 (4): 358-71.

2. Yoon HJ, Kim KH, Kim JY, Park HJ, Cho JY, Hong YJ. Chemotherapy-Induced Left Ventricular Dysfunction in Patients with Breast Cancer. J Breast Cancer 2016; 19 (4): 402-9.

3. Budowski M, Schief S, Sieber R. Precariousness and Quality of Life a Qualitative Perspective
عظمت و كرامت او، ايثار و از خود گذشتخى در راه رضاى او و تداوم ياد او را در بيى خواهد داشت (1). به نظر مى رسد كه اعتقاد به خدا، به بيماران سرطانى، قدرت مى دهد و افراد معتقد باور مى كنند كه در

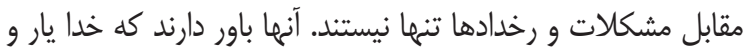

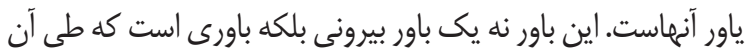

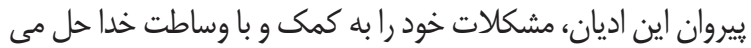
كنند. شايد ظاهر امر اين طور باشد كه اين گروهاز انسان ها گرايش بيرونى دارند ولى اين طور نيست. آنما معتقد نيستند خدا مشكلات

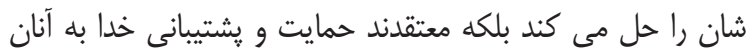
نيرو مى دهد تا بر بيماريشان فائق آيند. در اصل، گسترش معنويت با

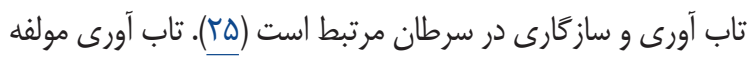
اي است كه بين آسيب يذيرى و توانايى هاى افراد موازنه برقرار مى

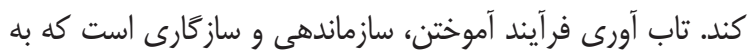
افراد كمك مى كند تا از سلامتى، شادى و زندگى معنى دار در مقابل استرس هاى درونى و بيرونى دفاع كنند (عب). به تعبير قرآن، خسران و بدبختى آنجا است كه آدمى، روح و و اميد خود

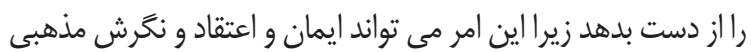
وى را تحت تاثير قرار دهد و در نتيجه اين بيماران آسيب يذيرى بيشترى خواهند داشت. بيمارى سرطان تمام جنبه هاى زندگى فرد

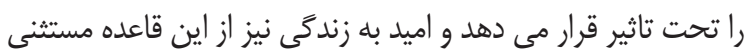
نمى باشد، بنابراين داشتن نخرش هاى مذهبى قوى مى تواند تاب آورى بيمار را افزايش دهد.

روى هم رفته مى توان كَت بيماران سرطانى با توجه به باورهاى مذهبى و يذيرش احتمال آسيبهاى شديد جسمى و روانى به كمى ركى ايمان و نخرش دينى، به سازگارى و تاب آورى دست مى يابند، به به به اين ترتيب در خصوص نتايج بدست آمده از بررسى تحقيق حاضر، يبيشنهاد مى شود كه مديريت بيمارستان (محلى كه بيماران سرطانى بردي

on Quality of Life of Households in Precarious Prosperity in Switzerland and Spain. Appl Res Qual Life 2016; 11 (4): 1035-58.

4. Eiser $\mathrm{CH}$, Lawrence E. Children with cancer: The quality of life. New Jersey, USA. 2006.

5. Golderberg D, Williams P. A user's guide to the General Health questionnaire. Windsor, UK: NFER-Nelson. 2008.

6. Souri H, Hasanirad T. Relationship between Resilience, Optimism and Psychological WellBeing in Students of Medicine a School of Educational Psychology, Psychology and Education Faculty. Universityof Tehran, Iran. 
2012.

7. Huang, C. Hardiness and stress: A critical review. Maternal Child Nursing Journal 2007; 2 (3): 8289.

8. Mirzaeirad SZ, Arsalani N, Dalvandi A, Soltani PR. The effect of resiliency skills training on jobstress in nurses of Golestan Hospitals.M.Sc. Theses. University of Social Welfare and Rehabilitation. Tehran; Iran, 2015. (Persian).

9. Tarantino B, Earley M, Audia DD, Adamo C, Berman B. Qualitative and quantitative evaluation of a pilot integrative coping and resiliency program for healthcare professionals. Explore, 2013; 9 (1): 44-47.

10. Khlatbari j, Bahari S. The relationship between resiliency and life satisfaction. Journal of Educational Psychology, Islamic Azad University Tonekabon 2010; 1 (2): 83-94. (Persian).

11. Shojaee S, Beh-Pajooh, A. The effectiveness of resilience training on resilience and its component in siblings of children with Down syndrome. Research on Exceptional Children, 2015; 2: 5-17. (Persian).

12. Zakavi A, Marzband R. The study of instructors spiritual factors in medical science education by emphasizing on revealed teachings. Relig Health. 2013; 1 (1): 33-46.

13. Highfield MF. Spiritual health of oncology patients: nurse and patient perspectives. Cancer Nursing 2002; 15: 1-10.

14. Allahbakhshian $M$, Jaffarpour M, Parvizy S, Haghani H. A Survey on relationship betweenspiritual wellbeing and quality of life in multiple sclerosis patients. Zahedan Journal of Research inMedical Sciences, Journal of Zahedan University of Medical Sciences (Tabibe-shargh), 2010, 12 (3): 29-33.

15. King D. Rethinking claims of spiritual intelligence: a definition, model and measure Applications of modeling in the Natural and social sciences program. Trent university. 2008. P.11.

16. Ironson G, Stuetzle R, Fletcher MA. An increase in religiousness/spirituality occurs after HIV diagnosis and predicts slower disease progression over 4 years in people with HIV. Journal of general internal Medicine. J Gen Intern Med. 2006; 21 (5): 62-68.

17. Haghi Garmi Hassan, Nazemi Aaliyah, $\checkmark$
Karimullahi Mansoureh. The Role of Personality Factors and Religious Beliefs in Rescuing Patients with Esophageal Cancer. Journal of Health and Care 2016, 18 (2): 152-170. (Persian).

18. Harafi A. Anticipating the weakening of religious records in patients with leukemia. First National Conference on Psychology and Educational Sciences of Iran, Kerman, Gorgan Conference 2016. (Persian).

19. Fradelos, E. C., Latsou, D., Mitsi, D., Tsaras, K., Lekka, D., Lavdaniti, M., Tzavella, F., ... Papathanasiou, I. V. Assessment of the relation between religiosity, mental health, and psychological resilience in breast cancer patients. Contemporary oncology (Poznan, Poland) 2018, 22 (3), 172-177.

20. Guan Chong Ng, Salina Mohamed, Ahmad Hatim Sulaiman, Nor Zuraida Zaina(2017), Anxiety and Depression in Cancer Patients: The Association with Religiosity and Religious Coping, Journal of Religion and Health, 2017, 56 (2): 575-582.

21. Dewi, Triana Kesuma; PETERS, Madelon L.; MARGONO, Benjamin P. The Effect of Religiosity Mediated by Acceptance on Quality of Life: A Study on Muslim Patients with Cancer in Palliative Care. GSTF Journal of Law and Social Sciences (JLSS), 2017; [S.1.], v. 2, n. 2, dec. 2017. ISSN 2251-2861.

22. Renske Kruizinga , Michael Scherer-Rath , Johannes B. A. M. Schilderman, Mariëtte Weterman, Teresa Young and Hanneke W. M. van Laarhoven(2017), Images of God and attitudes towards death in relation to spiritual wellbeing: an exploratory side study of the EORTC QLQ-SWB32 validation study in palliative cancer patients, BMC Palliative Care 16:67 DOI 10.1186/s12904-017-0251-7.

23. Imbs J, Mejean I. Elasticity optimism. Am Econ J Macroecon 2015;7 (3): 43-83.

24. Carver CS, Scheier MF. Dispositional optimism. Trends Cogn Sci. 2014; 18 (6): 293-9.

25. Zerach G, Karstoft K, Solomon Z. Hardiness and sensation seeking as potential predictors of former prisoners of wars' posttraumatic stress symptoms trajectories over a 17-year period. Journal of Affective Disorders. 2017; 218: 17681.

26. Salim J, Wadey R, Diss C. Examining the 
نشريه مراقبت سرطان، دوره اول، شماره ؟، تابستان 99"1

relationship between hardiness and perceived stress-related growth in a sport injury context.

Psychology of Sport and Exercise. 2015; 19 (3):

10-17. 